\title{
Altered expression of the TCR signaling related genes CD3 and FceRly in patients with aplastic anemia
}

\author{
Bo Li ${ }^{1,2}$, Sichu Liu', Yuzhe Niu', Su Fang ${ }^{1}$, Xiuli Wu', Zhi Yu', Shaohua Chen', Lijian Yang ${ }^{1}$ and Yangqiu Li ${ }^{1,2^{*}}$
}

\begin{abstract}
Background: Aplastic anemia (AA) is characterized by pancytopenia and bone marrow hypoplasia, which results from immune-mediated hematopoiesis suppression. Understanding the pathophysiology of the immune system, particularly T cells immunity, has led to improved AA treatment over the past decades. However, primary and secondary failure after immunosuppressive therapy is frequent. Thus, knowledge of the immune mechanisms leading to AA is crucial to fundamentally understand the disease.
\end{abstract}

Findings: To elucidate the T cell receptor (TCR) signal transduction features in AA, the expression levels of CD3 $\gamma, \delta$, $\varepsilon$ and $\zeta$ chain and FCERly genes, which are involved in TCR signal transduction, and the negative correlation of the

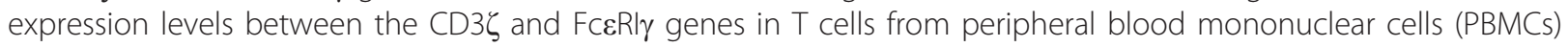
were analyzed. Real-time RT-PCR using the SYBR Green method was used to detect the expression level of these genes in PBMCs from 18 patients with $A A$ and 14 healthy individuals. The $\beta 2$ microglobulin gene $(\beta 2 M)$ was used as an endogenous reference. The expression levels of the $C D 3 \gamma, C D 3 \delta, C D 3 \varepsilon$ and $C D 3 \zeta$ genes in patients with $A A$ were significantly increased compared to a healthy control group, whereas the Fc\&Rl $\gamma$ gene expression level was significantly decreased in patients with AA in comparison with the healthy control group. Moreover, the negative correlation of the expression levels between the $\mathrm{CD} 3 \zeta$ and FceRly genes was lost.

Conclusions: To our knowledge, this is the first report of the $\mathrm{CD} 3 \gamma, \mathrm{CD} 3 \delta, \mathrm{CD} 3 \varepsilon, \mathrm{CD} 3 \zeta$ and $\mathrm{F} c \varepsilon \mathrm{R} l \gamma$ gene expression in patients with AA. The abnormally expressed TCR signaling related genes may relate to T cells dysfunction in AA.

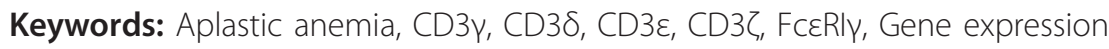

\section{Introduction}

Aplastic anemia (AA) is a potentially fatal bone marrow failure disorder that is characterized by pancytopenia and bone marrow hypoplasia. In most cases, AA behaves as an immune-mediated disease [1]. Immunosuppression is a key treatment strategy for patients who are not suitable bone marrow transplant (BMT) candidates due to age or the lack of a suitable donor. Immunosuppression with antithymocyte globulins and cyclosporine is effective for restoring blood cell production in the majority of patients $[2,3]$. The thought that $\mathrm{T}$ cells play a major role in the pathophysiology of AA became evident in the late 1970s

\footnotetext{
* Correspondence: yangqiuli@hotmail.com

'Institute of Hematology, Medical College, Jinan University, Guangzhou 510632, China

Full list of author information is available at the end of the article
}

with the finding that marrow and peripheral blood lymphocytes from patients with AA were able to suppress hematopoiesis in vitro. Subsequently, activated CD8 ${ }^{+}$ $\mathrm{T}$ cells were identified as the lymphocyte subset that inhibited hematopoiesis in AA patients [4]. Further studies have indicated that the mechanism includes Fasinduced apoptosis [5] and the release of several inhibitory cytokines including $\gamma$-interferon (IFN- $\gamma$ ), tumor necrosis factor- $\alpha$ (TNF- $\alpha$ ) and transforming growth factor $-\beta$ (TGF- $\beta$ ) [6-8]. Subsequent studies have demonstrated that oligoclonal expanded cytotoxic $\mathrm{T}$ cells target hematopoietic stem and progenitor cells [1]. All of these findings suggest that the molecular basis of the aberrant immune response and deficiencies in hematopoietic cells is $\mathrm{T}$ cells activation pathway dysregulation [9].

\section{Biomed Central}


When $\mathrm{T}$ cells encounter antigens via the TCR, information about the quantity and quality of antigen engagement is relayed to the intracellular signal transduction machinery. The TCR lacks a significant intracellular domain. Instead, it associates with CD3 molecules, which contain intracellular signaling domains that couple the TCR/CD3 complex to downstream signaling machinery. The earliest TCR signaling events involve the transfer of information from the antigen-binding TCR subunit to the CD3 signaling subunits in the TCR/CD3 complex [10]. The Fc epsion receptor type I $\gamma$ (FceRI $\gamma$ ) chain is a member of the $\mathrm{CD} 3 \zeta$ chain protein family, and it is a component of the high-affinity IgE receptor FceRI. There is evidence that the FceRI $\gamma$ chain can replace a functionally deficient $\mathrm{CD} 3 \zeta$ chain and facilitate TCR/CD3 complex-mediated signaling $[11,12]$.

Growing evidence has shown that AA is a type of autoimmune disease that involves a $\mathrm{T}$ cell attack against hematopoietic progenitor cells [13]. Oligoclonal T cells expansion was detected in autoimmune diseases such as systemic lupus erythematosus (SLE), rheumatoid arthritis and multiple sclerosis [14-17]. The TCR/CD3 signaling complex appears to be down-regulated by mutations/polymorphisms in autoimmune diseases, chronic inflammation and malignant tumors, which are thought to be related to $\mathrm{T}$ cells immunodeficiency $[18,19]$.

Antigen-specific $\mathrm{T}$ cells play a central role in immune and inflammatory responses. An appropriate immune response by these cells depends on the careful regulation of their activation. However, little is known about the expression pattern of the CD3 complex and FceRI $\gamma$ genes in AA patients. We concluded that analysis of these genes in AA patients during their initial presentation may serve to identify the abnormal immune characteristics of AA.

\section{Methods}

\section{Samples}

The AA group consisted of 18 patients with newly diagnosed AA (12 males and 6 females; median age: 21 years, range: 8-73 years). Two of the cases were collected after immunosuppression treatment (ATG + CsA) at different time points (i.e., 1, 3 or 4 months). The information and clinical data of patients were described in Table 1 and 2 . Fourteen healthy individuals ( 9 males and 5 females; median age: 24.5 years, range: $12-65$ years) served as the control group. The AA diagnosis was established by bone marrow biopsy and peripheral blood counts. All of the procedures were performed according to the guidelines of the Medical Ethics committee of the health bureau of the Guangdong Province of China. Peripheral blood mononuclear cell (PBMC) isolation, RNA extraction and cDNA synthesis were performed according to the manufacturer's instructions.

\section{Real-time relative quantitative PCR for $\mathrm{CD} 3 \gamma \delta \varepsilon \zeta$ and Fc£Rly genes}

Real-time PCR using the SYBR Green I method was used to examine the CD $3 \gamma, \delta, \varepsilon, \zeta$ and FceRI $\gamma$ gene expression levels using cDNA obtained from the PBMCs of the 18 patients. The primer sequences and PCR conditions have been previously described [20]. Briefly, the

Table 1 Clinical data of AA patient

\begin{tabular}{|c|c|c|c|c|c|}
\hline Case number & Age (years) & Sex & $\mathrm{Hb}(\mathrm{g} / \mathrm{L})$ & ANC $\left(10^{9} / \mathrm{L}\right)$ & PLT $\left(10^{9} / \mathrm{L}\right)$ \\
\hline 1 & 10 & Female & 60 & 0.1 & 69 \\
\hline 2 & 17 & Male & 112 & 1.2 & 39 \\
\hline 3 & 24 & Male & 40 & 0.3 & 42 \\
\hline 4 & 12 & Male & 69 & 0.8 & 24 \\
\hline 5 & 14 & Female & 55 & 0.4 & 29 \\
\hline 6 & 28 & Male & 87 & 0.8 & 90 \\
\hline 7 & 27 & Male & 67 & 0.3 & 45 \\
\hline 8 & 19 & Male & 91 & 0.7 & 29 \\
\hline 9 & 73 & Male & 59 & 1.1 & 94 \\
\hline 10 & 15 & Female & 81 & 0.4 & 63 \\
\hline 11 & 8 & Female & 65 & 0.4 & 12 \\
\hline 12 & 19 & Female & 74 & 0.1 & 52 \\
\hline 13 & 18 & Male & 71 & 0.1 & 45 \\
\hline 14 & 48 & Male & 40 & 0.1 & 24 \\
\hline 15 & 57 & Male & 83 & 0.3 & 30 \\
\hline 16 & 31 & Male & 47 & 0.5 & 21 \\
\hline 17 & 35 & Female & 63 & 0.1 & 20 \\
\hline 18 & 26 & Male & 108 & 0.2 & 12 \\
\hline
\end{tabular}


Table 2 Clinical data of follow-up patients

\begin{tabular}{|c|c|c|c|c|}
\hline Case number & Time & $\mathrm{Hb}(\mathrm{g} / \mathrm{L})$ & ANC $\left(10^{9} / \mathrm{L}\right)$ & PLT $\left(10^{9} / \mathrm{L}\right)$ \\
\hline 1 & $\begin{array}{c}\text { Before treatment } \\
4 \text { months after treatment }\end{array}$ & $\begin{array}{l}60 \\
66\end{array}$ & $\begin{array}{l}0.1 \\
0.6\end{array}$ & $\begin{array}{l}69 \\
45\end{array}$ \\
\hline \multirow[t]{2}{*}{2} & $\begin{array}{l}\text { Before treatment } \\
1 \text { months after treatment }\end{array}$ & $\begin{array}{l}112 \\
119\end{array}$ & $\begin{array}{l}1.2 \\
1.1\end{array}$ & $\begin{array}{l}39 \\
43\end{array}$ \\
\hline & 3 months after treatment & 124 & 1.6 & 47 \\
\hline
\end{tabular}

PCR reactions were performed in a total volume of 25 $\mu \mathrm{l}$ containing approximately $1 \mu \mathrm{l} \mathrm{cDNA}, 0.5 \mu \mathrm{M}$ of each primer pair, and $11.25 \mu \mathrm{l} 2.5 \times$ RealMasterMix (Tiangen, Beijing). After an initial denaturation at $95^{\circ} \mathrm{C}$ for $2 \mathrm{~min}$, 45 cycles consisting of the following procedure was performed using an MJ Research DNA Engine Opticon 2 PCR cycler (BIO-RAD, Hercules, CA, USA): $15 \mathrm{~s}$ at $95^{\circ}$ $\mathrm{C} ; 1 \mathrm{~min}$ at $58.9^{\circ} \mathrm{C}$ for $\beta 2 \mathrm{M}$ and $\mathrm{CD} 3 \gamma, 60^{\circ} \mathrm{C}$ for $\mathrm{CD} 3 \zeta$ and Fc\&RI $\gamma, 60.8^{\circ} \mathrm{C}$ for $\mathrm{CD} 3 \delta$, and $62^{\circ} \mathrm{C}$ for $\mathrm{CD} 3 \varepsilon$; and 1 $s$ at $82^{\circ} \mathrm{C}$ for plate reading. The $2^{(-\Delta \mathrm{CT})}$ method was used to analyze the results of the genes of interest relative to an internal control gene [21].

\section{Statistical analysis}

An independent-samples $t$ test was performed to compare the mean of each gene expression level between the patients with AA and the control groups. Pearson correlation and linear regression analyses were used to estimate the correlation between the CD3 $\zeta$ and FceRI $\gamma$ gene expression levels from the different groups. A $P<$ 0.05 was considered statistically significant.

\section{Results and discussion}

The gene expression levels of CD3 $\gamma, \mathrm{CD} 3 \delta, \mathrm{CD} 3 \varepsilon, \mathrm{CD} 3 \zeta$ and FceRI $\gamma$ in cDNA obtained from the PBMCs of 18 patients with AA before treatment and 14 healthy individuals were quantitatively assessed by real-time PCR using the SYBR Green I method.

All five genes were detected in every sample. Significantly higher expression levels of CD3 $\gamma(17.84 \pm 20.97$, $p=0.015), \mathrm{CD} 3 \delta(3.24 \pm 2.61, p=0.002), \mathrm{CD} 3 \varepsilon(15.73 \pm$ $11.44, p=0.000)$, and $\mathrm{CD} 3 \zeta(5.65 \pm 3.51, p=0.000)$ were observed in patients with AA compared to the healthy

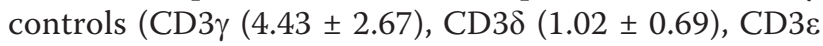
$(3.36 \pm 2.09)$, and $\mathrm{CD} 3 \zeta(1.83 \pm 1.21)$ for the healthy controls; Figure 1). In contrast, significantly lower Fc\&RI $\gamma$ expression levels $(17.63 \pm 9.95)$ were found in the AA group compared to the healthy group $(30.55 \pm 23.21, p=$ 0.041).

The expression level of all five genes was compared in two patients with AA before and after treatment. The expression levels of the $\mathrm{CD} 3 \gamma, \mathrm{CD} 3 \delta, \mathrm{CD} 3 \varepsilon$ and $\mathrm{CD} 3 \zeta$ genes decreased, and the FceRI $\gamma$ expression level of increased after treatment (Figure 2A, B). The CD3 $\gamma$ expression level decreased from 34.03 to 1.31 , the $\mathrm{CD} 3 \delta$ expression level decreased from 3.36 to 0.52 , the CD3 $\varepsilon$ expression level decreased from 45.06 to 2.96 , the CD3 expression level decreased from 10.96 to 0.86 , and the Fc\&RI $\gamma$ expression level increased from 5.97 to 107.55 in the 3 months after treatment in 1 case (Figure 2A). The expression levels of $\mathrm{CD} 3 \delta, \mathrm{CD} 3 \varepsilon$ and $\mathrm{CD} 3 \zeta$ returned to the normal range compared to the healthy group, whereas the

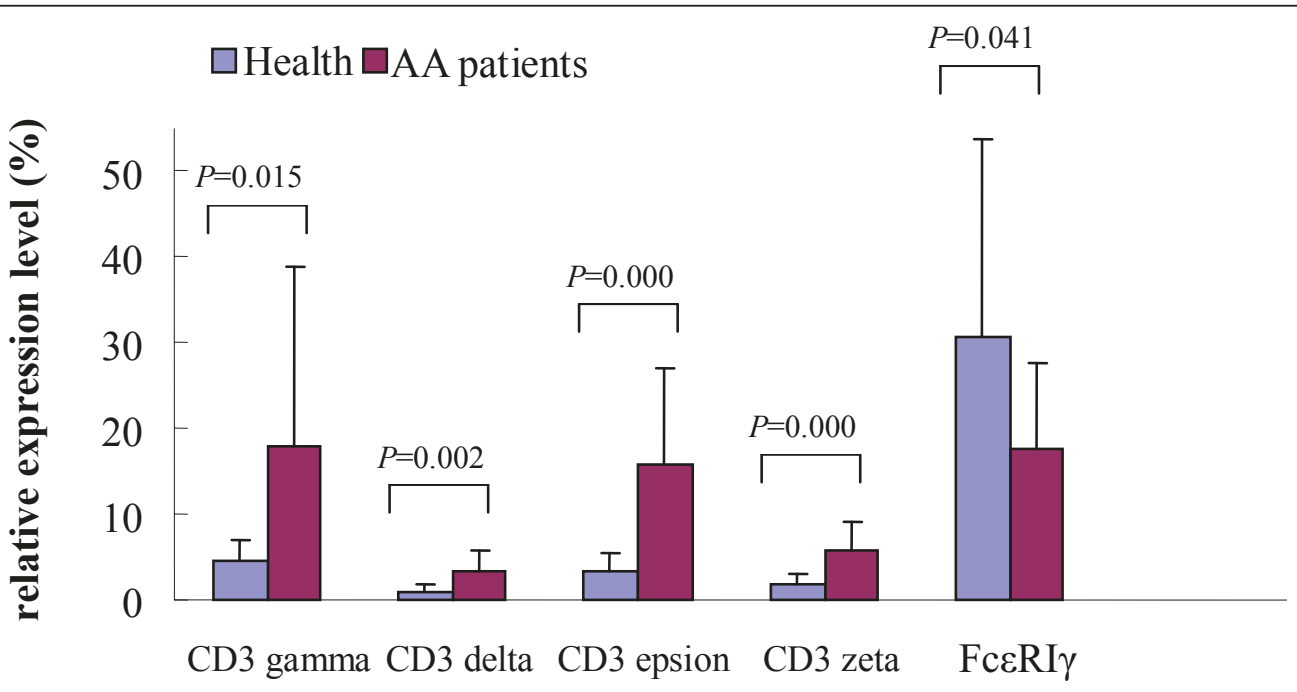

Figure 1 The relative gene expression levels of $\mathrm{CD} 3 \gamma, \mathrm{CD} 3 \delta, \mathrm{CD} 3 \varepsilon, \mathrm{CD} 3 \zeta$ and $\mathrm{Fc} \varepsilon \mathrm{Rl} \gamma$ in PBMCs from the $\mathrm{AA}$ and healthy groups. 

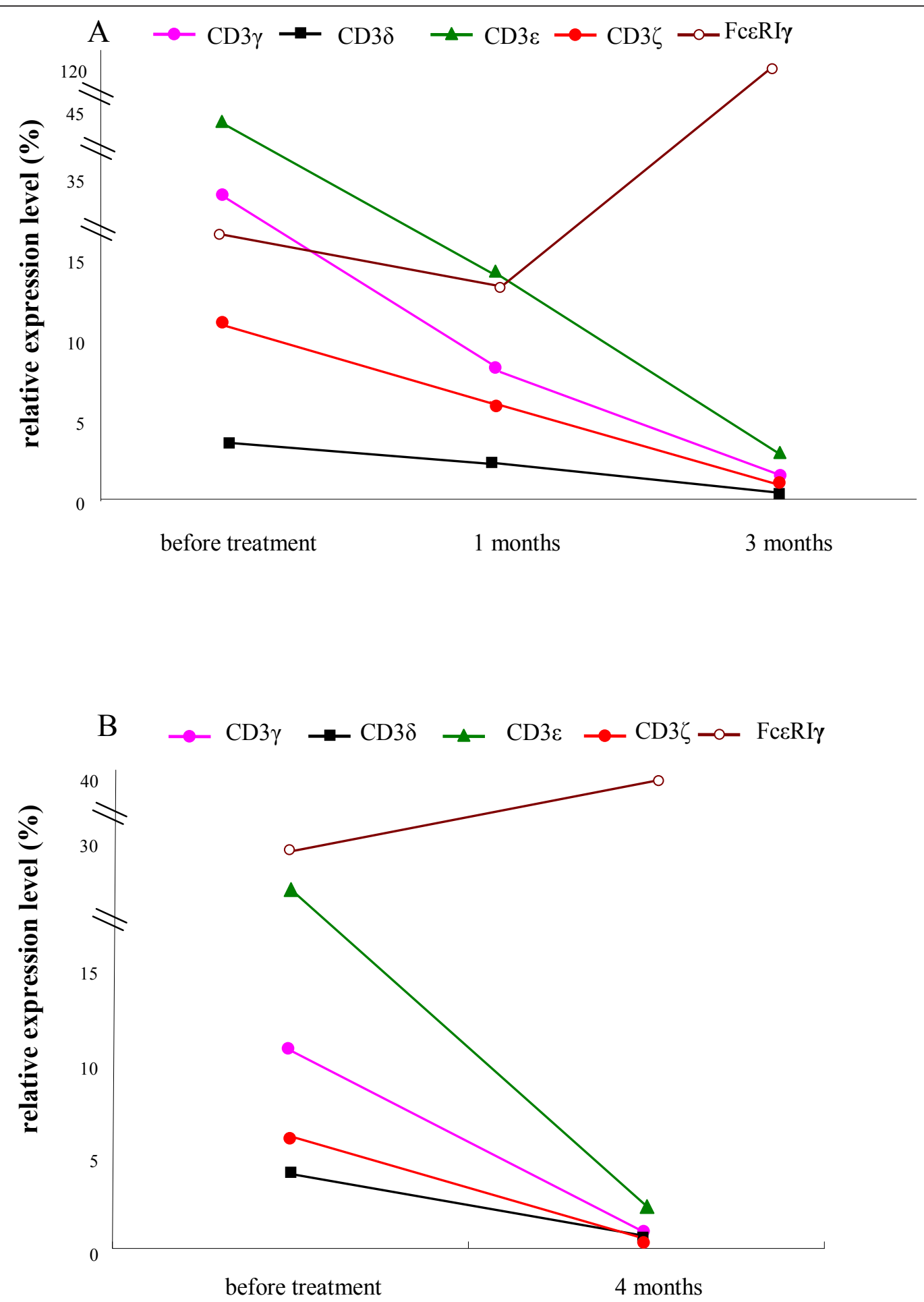

Figure 2 The relative gene expression levels of $\mathrm{CD} 3 \gamma, \mathrm{CD} 3 \delta, \mathrm{CD} 3 \varepsilon, \mathrm{CD} 3 \zeta$ and Fc\&Rl $\gamma$ in the PBMCs from 2 patients after treatment

CD3 $\gamma$ and FceRI $\gamma$ expression levels did not. In another case, the CD3 $\gamma$ expression level decreased from 10.57 to 0.82 , the CD3 $\delta$ expression level decreased from 3.95 to 0.63 , the CD3 $\varepsilon$ expression level decreased from 19.14 to 2.23 , the
CD3ל expression level decreased from 5.91 to 0.54 , and the FceRI $\gamma$ expression level increased from 30.89 to 36.60 in the 4 months after treatment (Figure 2B). With the exception of the expression levels of CD3 $\gamma$ and $C D 3 \zeta$, which 
remained out of the normal range, the expression levels of the other genes returned to normal.

A significant negative correlation between the $\mathrm{CD} 3 \zeta$ and FceRI $\gamma$ gene expression levels was found in the healthy group $(\mathrm{r}=-0.535, p=0.049$; Figure $3 \mathrm{~A})$, while there was no significant correlation between the expression levels of the genes in the AA group ( $\mathrm{r}=0.252, p=$ 0. 313; Figure 3B).

The TCR has a short intracellular sequence that lacks signaling capacity, and the CD3 molecule contains immunoreceptor tyrosine-based activation motifs (ITAMs), which couple the TCR to the signal transduction mechanism. In mature T-lymphocytes, the TCR/ CD3 complex can essentially trigger all adaptive immune responses [22,23]. TCR signal transduction is mediated by the ITAMs. A total of 10 ITAMs are distributed in the TCR/CD3 complex in two distinct signaling modules termed the TCR $\zeta \zeta$ and $C D 3 \gamma \varepsilon / \delta \varepsilon[24,25]$. Although the TCR $\zeta \zeta$ ITAM plays a central role in TCR signal transmission, the CD $3 \gamma \varepsilon / \delta \varepsilon$ ITAM module can provide normal TCR signal transmission in the absence of a TCR $\zeta \zeta$ ITAM motif [26]. To gain more insight into TCR signal transduction, which is important for $\mathrm{T}$ cells activation, we analyzed the expression level of all four CD3 genes (i.e., $\mathrm{CD} 3 \gamma, \mathrm{CD} 3 \delta, \mathrm{CD} 3 \varepsilon$ and $\mathrm{CD} 3 \zeta$ ) and the $\mathrm{CD} 3 \zeta$-related FceRI $\gamma$ gene in PBMCs from patients with AA.

In contrast with recent studies that have revealed decreased $\mathrm{CD} 3 \zeta$ chain protein and mRNA levels in most patients with AA, their results were derived from only five newly diagnosed patients with AA and patients (25 cases) in remission or relapse [27]. In this study, we analyzed the expression pattern of all of the CD3 genes, and the data indicated that not only the $\mathrm{CD} 3 \zeta$, but also the CD3 $\gamma$, CD3 $\delta$ and $C D 3 \varepsilon$ expression levels were significantly increased in comparison with those in the healthy group. The results suggested that there may be a different $T$ cells signaling pathway activation disorder in AA. Like many other cell surface receptors, TCR/CD3 complexes are constitutively internalized and recycled back to cell surface. This downmodulation of TCR/CD3 at the cell surface prevents sustained signalling in T-APC conjugates and modulates the responsiveness of $\mathrm{T}$ cells to further antigenic stimulation [28]. Up-regulation of CD3 gene expression in AA suggests that $\mathrm{T}$ cells may be in sustained signaling stimulation in the periphery that leads to inappropriate $\mathrm{T}$ cell activation.

Unlike the $\mathrm{CD} 3 \zeta$ chain, which mediates signaling through ZAP-70, FceRI $\gamma$ mediates signaling by associating with the phosphorylated protein kinase Syk [12,29]. It has been reported that the Syk kinase is 100 -fold more potent than Zap-70 [30], and it is preferentially recruited to the FceRI $\gamma$ [31]. Krishnan et al. have found a physiological switch through which primary resting $\mathrm{CD} 4^{+} \mathrm{T}$ cells

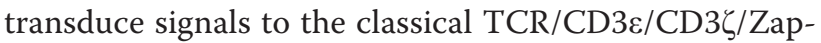
70 complex, and effector $\mathrm{CD} 4^{+} \mathrm{T}$ cells express and transduce signals through an alternate TCR signaling complex

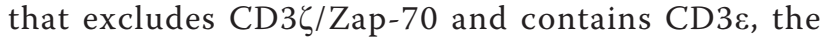
FceRI $\gamma$ subunit and the proximal Syk kinase [32]. It is interesting that this physiological switch in the TCR/CD3 signaling complex is not observed in $\mathrm{CD}^{+} \mathrm{T}$ cells [33]. The TCR signaling alterations identified in our study suggest that the reduction in FceRI $\gamma$ expression in AA was unable to contribute to TCR signal transduction in a similar manner as the conserved functional ITAM motif.

In this study, we first analyzed the FceRI $\gamma$ gene expression level and its correlation with $\mathrm{CD} 3 \zeta$ gene expression in patients with AA; the FceRI $\gamma$ expression level was down-regulated and did not correlate with the CD3 $\zeta$ expression level. These findings are in contrast to the immune status in SLE [12], where a lower CD3 3 expression is associated with a higher FceRI $\gamma$ expression level. These data suggest that the different dysregulated $\mathrm{T}$ cells activation pathways involved in AA may be more complicated, and AA is unlikely to be a typical autoimmune disease $\mathrm{T}$ cells disorder. We were unable to follow up with the clinical outcome of all the patients who

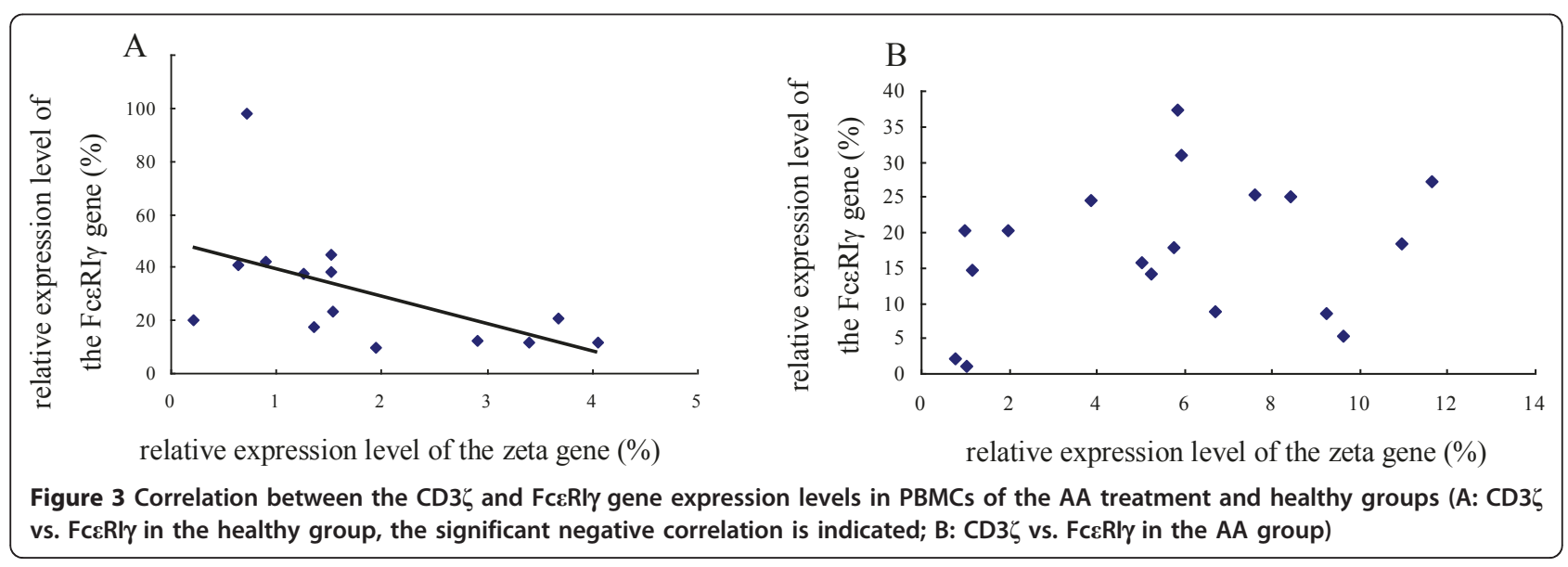


were selected for this study. We monitored the change in the $\mathrm{CD} 3 \gamma, \mathrm{CD} 3 \delta, \mathrm{CD} 3 \varepsilon, \mathrm{CD} 3 \zeta$ and FceRI $\gamma$ gene expression levels in 2 patients with AA who were in remission. All of the gene expression patterns changed relative to the normal level. These data suggest that the expression of these genes is disease status dependent. However, a limited number of patients (2 cases) were examined in this follow-up study; thus, this hypothesis should be confirmed in future studies with larger sample sizes.

\section{Conclusions}

To our knowledge, this study is the first attempt to provide a gene expression profile of the $\operatorname{CD} 3 \gamma, \delta$, $\varepsilon$, and $\zeta$ chains and the related FceRI $\gamma$ gene in PBMCs from patients with AA. Taken together, the increased $\mathrm{T}$ cells activation, along with the abnormally immunological molecules may be an AA feature. Abnormal T cells activation in AA creates a cellular imbalance between immunity and tolerance, leading to immune system-mediated bone marrow failure.

\section{Acknowledgements}

This study was sponsored by grants from the National Natural Science Foundation of China (No. 30972455), a China Postdoctoral Science Foundation funded project (No. 20070410840), the Natural Science Foundation of Guangdong province (No. 07301046), and the Fundamental Research Funds for the Central Universities (No. 2011610408).

\section{Author details}

${ }^{1}$ Institute of Hematology, Medical College, Jinan University, Guangzhou 510632, China. ${ }^{2}$ Key Laboratory for Regenerative Medicine of Ministry of Education, Jinan University, Guangzhou 510632, China.

\section{Authors' contributions}

YQL contributed to concept development and study design. BL, SHC, LJY performed the laboratory studies. SCL, YZN, SF, XLW and YZ were responsible for collection of clinical data. YQL and BL coordinated the study and helped drafting the manuscript. All authors read and approved the final manuscript.

\section{Competing interests}

The authors declare that they have no competing interests.

Received: 23 January 2012 Accepted: 8 March 2012

Published: 8 March 2012

\section{References}

1. Young NS, Scheinberg P, Calado RT: Aplastic anemia. Curr Opin Hematol 2008, 15:162-168.

2. Zhou F, Ge L, Yu Z, Fang Y, Kong F: Clinical observations on intensive immunosuppressive therapy combined with umbilical cord blood support for the treatment of severe aplastic anemia. J Hematol Oncol 2011, 4:27.

3. Sun ZM, Liu HL, Geng LQ, Wang XB, Yao W, Liu X, Ding KY, Han YS, Yang HZ, Tang BL, Tong J, Zhu WB, Wang ZY: HLA-matched sibling transplantation with G-CSF mobilized PBSCs and BM decreases GVHD in adult patients with severe aplastic anemia. J Hematol Oncol 2010, 3:51.

4. Zoumbos NC, Gasco'n P, Djeu JY, Trost SR, Young NS: Circulating activated suppressor T lymphocytes in aplastic anemia. N Engl J Med 1985, 312:257-265.

5. Maciejewski JP, Selleri C, Sato T, Anderson S, Young NS: Increased expression of Fas antigen on bone marrow $\mathrm{CD} 34^{+}$cells of patients with aplastic anaemia. Br J Haematol 1995, 91:245-252.
6. Zoumbos NC, Gascon P, Djeu JY, Young NS: Interferon is a mediator of hematopoietic suppression in aplastic anemia in vitro and possibly in vivo. Proc Natl Acad Sci USA 1985, 82:188-192.

7. Sloand E, Kim S, Maciejewski JP, Tisdale J, Follmann D, Young NS: Intracellular interferon-gamma in circulating and marrow T cells detected by flow cytometry and the response to immunosuppressive therapy in patients with aplastic anemia. Blood 2002, 100:1185-1191.

8. Dufour C, Giacchino R, Ghezzi P, Tonelli R, Ferretti E, Pitto A, Pistoia V, Lanza T, Svahn J: Etanercept as a salvage treatment for refractory aplastic anemia. Pediatr Blood Cancer 2009, 52:522-525

9. Young NS, Calado RT, Scheinberg P: Current concepts in the pathophysiology and treatment of aplastic anemia. Blood 2006, 108:2509-2519.

10. Call ME, Pyrdol J, Wucherpfenning KW: Stoichiometry of T-cell receptorCD3 complex and key intermediates assembled in the endoplasmic reticulum. EMBO J 2004, 23:2348-2357.

11. Koyasu S, D'Adamio L, Arulanandam AR, Abraham S, Clayton LK, Reinherz EL: T cell receptor complexes containing Fc epsilon RI gamma homodimers in lieu of CD3 zeta and CD3 eta components: a novel isoform expressed on large granular lymphocytes. J Exp Med 1992, 175:203-209.

12. Enyedy EJ, Nambiar MP, Liossis SN, Dennis G, Kammer GM, Tsokos GC: Fc epsilon receptor type I gamma chain replaces the deficient $\mathrm{T}$ cell receptor zeta chain in T cells of patients with systemic lupus erythematosus. Arthritis Rheum 2001, 44:1114-1121.

13. Kaito K, Otsubo H, Usui N, Kobayashi M: Th1/Th2 lymphocyte balance in patients with aplastic anemia. Rinsho Byori 2004, 52:569-573.

14. Murata $H$, Matsumura $R$, Koyama $A$, et al: T cell receptor repertoire of $T$ cells in the kidneys of patients with lupus nephritis. Arthritis Rheum 2002, 46:2141-2147.

15. Kato T, Kurokawa M, Sasakawa H, Masuko-Hongo K, Matsui T, Sekine T, Tanaka C, Yamamoto K, Nishioka K: Analysis of accumulated T cell clonotypes in patients with systemic lupus erythematosus. Arthritis Rheum 2000, 43:2712-2721.

16. Thompson SD, Murray KJ, Grom AA, Passo MH, Choi E, Glass DN: Comparative sequence analysis of the human T cell receptor beta chain in juvenile rheumatoid arthritis and juvenile spondylarthropathies: evidence for antigenic selection of T cells in the synovium. Arthritis Rheum 1998, 41:482-497.

17. Amemiya K, Granger RP, Dalakas MC: Clonal restriction of T-cell receptor expression by infiltrating lymphocytes in inclusion body myositis persists over time. Studies in repeated muscle biopsies. Brain 2000, 123:2030-2039.

18. Ciszak L, Pawlak E, Kosmaczewska A, Potoczek S, Frydecka I: Alterations in the expression of signal-transducing CD3 zeta chain in T cells from patients with chronic inflammatory/autoimmune diseases. Arch Immunol Ther Exp (Warsz) 2007, 55:373-386.

19. Li Y: Alterations in the expression pattern of TCR zeta chain in T cells from patients with hematological diseases. Hematology 2008, 13:267-275.

20. Chen S, Zha X, Yang L, Li B, Zhong L, Li Y: Deficiency of CD3gamma, delta, epsilon and zeta expression in T-cells from AML patients. Hematology 2011, 16:31-36.

21. Livak KJ, Schmittgen TD: Analysis of relative gene expression data using real-time quantitative PCR and the 2(-Delta Delta C(T)) Method. Methods 2001, 25:402-408.

22. Clevers H, Alarcon B, Wileman T, Terhorst C: The T-cell receptor/CD3 complex: A dynamic protein ensemble. Annu Rev Immunol 1988, 6:629-662.

23. Call ME, Wucherpfenning KW: Molecular mechanisms for the assembly of the T cell receptor-CD3 complex. Mol Immunol 2004, 40:1295-1305.

24. Wegener AM, Letourneur F, Hoeveler A, Brocker T, Luton F, Malissen B: The T-cell receptor/CD3 complex is composed of at least two autonomous transduction modules. Cell 1992, 68:83-95.

25. Malissen B: An evolutionary and structural perspective on T-cell antigen receptor function. Immunol Rev 2003, 191:7-27.

26. Pitcher LA, Mathis MA, Young JA, DeFord LM, Purtic B, Wulfing C, van Oers NS: The CD3 gamma epsilon/delta epsilon signaling module provides normal T cell functions in the absence of the TCR zeta immunoreceptor tyrosine-based activation motifs. Eur J Immunol 2005, 35:3643-3654. 
27. Solomou EE, Wong S, Visconte V, Gibellini F, Young NS: Decreased TCR zeta-chain expression in T cells from patients with acquired aplastic anaemia. Br J Haematol 2007, 138:72-76.

28. Zanders ED, Lamb JR, Feldmann M, Green N, Beverley PC: Tolerance of Tcell clones is associated with membrane antigen changes. Nature 1983, 303:625-627.

29. Shiue L, Zoller MJ, Brugge JS: Syk is activated by phosphotyrosinecontaining peptides representing the tyrosine-based activation motifs of the high affinity receptor for lgE. J Biol Chem 1995, 270:10498-10502.

30. Oliver JM, Burg D, Wilson BS, McLaughlin JL, Geahlen RL: Inhibition of mast cell FcrRl-mediated signaling and effector function by the Syk-selective inhibitor, piceatannol. J Biol Chem 1994, 269:29697-29703.

31. Taylor N, Jahn T, Smith S, Lamkin T, Uribe L, Liu Y, et al: Differential activation of the tyrosine kinases ZAP-70 and Syk after FcgRI stimulation. Blood 1997, 89:388-396.

32. Krishnan S, Warke VG, Nambiar MP, Tsokos GC, Farber DL: The FcR gamma subunit and Syk kinase replace the CD3 zeta-chain and ZAP-70 kinase in the TCR signaling complex of human effector CD4 T cells. J Immunol 2003, 170:4189-4195.

33. Kersh EN, Kaech SM, Onami TM, Moran M, Wherry EJ, Miceli MC, Ahmed R: TCR signal transduction in antigen-specific memory CD8 T cells. J Immunol 2003, 170:5455-5454.

doi:10.1186/1756-8722-5-6

Cite this article as: Li et al:: Altered expression of the TCR signaling related genes $\mathrm{CD} 3$ and FceRly in patients with aplastic anemia. Journal of Hematology \& Oncology 2012 5:6.

\section{Submit your next manuscript to BioMed Central and take full advantage of:}

- Convenient online submission

- Thorough peer review

- No space constraints or color figure charges

- Immediate publication on acceptance

- Inclusion in PubMed, CAS, Scopus and Google Scholar

- Research which is freely available for redistribution

Submit your manuscript at www.biomedcentral.com/submit 